\title{
Daily soil carbon dioxide flux under different tillage conditions
}

\author{
Ágnes Törő - Péter Ragán - Tamás Rátonyi - Károly Kith - Endre Harsányi \\ University of Debrecen, Faculty of Agricultural and Food Sciences and Environmental Management \\ 4032 Debrecen, 138 Böszörményi str. \\ agnes.toro91@gmail.com
}

\begin{abstract}
SUMMARY
Over the last few years, warming of the atmospheric layer near Earth's surface is increasingly experienced and researchers have also established that concentration of numerous greenhouse gases have risen over the past two centuries value. Change is basically a legitimate process - considering atmospheric concentration as well - but the change experienced during the past centuries could not have become this critical without the contribution of human activity. Due to the nature of the greenhouse effect, the result of a very fragile, complex process is experienced currently on Earth, which can be significantly unbalanced even by a slight change. Carbon dioxide emitted from the soil is involved in the global cycle and has an impact on the greenhouse effect. The rise in soil respiration may result in the further intensification of warming. In the scope of the present study, it was examined how carbon dioxide emissions of the soil evolve over a day. The results have been established based on the comparison of the effects of different parts of the day, tillage methods and irrigation.
\end{abstract}

Keywords: daily flux, carbon dioxide emission, cultivation, irrigation

\section{INTRODUCTION}

Global climate change is one of the most important challenges of our world and we are responsible for it. One of the greenhouse gases responsible for climate change is carbon dioxide, the concentration of which has been rising since the industrial revolution.

Examination of greenhouse gases leads us to the conclusion that carbon dioxide is the least active gas. Methane - as another significant gas component - is 21 times more active, dinitrogen oxide (nitrous oxide) is 206 times more, while CFC gases are 15,000 times more active in terms of absorbing and emitting radiation energy. Considering the above, it is a reasonable question why carbon dioxide is still the most important element of the warming process. The answer can be explained by its high atmospheric concentration and the time spent there (Bartholy and Pongrácz, 2013).

The carbon cycle belongs to the most complex natural processes of our planet. Fixed carbon can be found in the atmosphere, in the ocean and in the biosphere; it is wandering around in these three spheres (Dunn, 2001). In the course of soil respiration, root respiration and microbial degradation processes are the basis for the emission of carbon dioxide into the atmosphere, which is one of the most important factors in terms of material flow of our planet (Hanson et al., 2000; Kuzyakov, 2006). The amount of carbon content within the soil is also largely influenced by human activity, which is mainly realized through deforestation and soil disturbances; degradation of organic matter considerably accelerates by these activities (Borken et al., 2002). The climate-changing role of soil has not been the subject of research for a long time, but from the 1980s it has increasingly become a research area, depending on the increasing extent of global climate change (Robock et al., 1998; Wang and Elthair, 2000).
Earth's carbon dioxide emission has been investigated since the 1980s in the United States (Lal et al., 1998a, 1998b). Agriculture is a major contributor to the growth of carbon dioxide in the atmosphere, accounting for $20 \%$ of growth (Gyuricza, 2004). In the upper, approximately one-meter layer of the soil, the sored $\mathrm{CO} 2$ in volume is larger than the stored volume in the atmosphere, so altering in the upper soil layer can significantly increase the concentration of atmospheric carbon dioxide. Of the greenhouse gases in the atmosphere, carbon dioxide plays a major role. Its volume decreased significantly to about 180-300 ppm, compared to the level present on the Earth-Earth (Haszpra, 2004).

Gases released from the decomposition of the organic matter of the soil, or from soil respiration mainly carbon dioxide - are being emitted at increasing amounts with the rise of soil temperature (Schleisinger, 1977). Therefore, global climate change - through increasing soil temperature - has an impact on the carbon cycle of the biosphere. With the increase in soil respiration, global warming might keep intensifying (Kaye and Hart, 1998).

With regard to the trial, our research objective was to examine the daily flux of carbon dioxide emissions of the soil under different tillage methods.

\section{MATERIAL AND METHODS}

Our trial was set up and carried out at the Látókép experimental site, in the field of the soil cultivation trial, where three different soil cultivation methods (ploughing, strip tillage and subsoiling) were analysed in terms of their impact on soil. Measurements were performed five times in each part of the day with five minutes of incubation period, recording the initial and post-incubation emission values. The cylinders that were placed onto the ground had unique internal ventilation and they also have the same diameter (118 $\times 250 \mathrm{~mm}$ ). On completion of the measurements, the 
cylinders were ventilated, and if necessary, they were cleansed from the deposited soil samples. Our measurements were carried out using a Testo 535 measuring device (Testo $\mathrm{SE} \& \mathrm{Co}$.), which is a $\mathrm{CO}_{2}$ gas analyser operating via infrared absorption. (Figure 1).

Our measurements were performed in the early hours of the morning ( 6 a.m.), then in the morning ( 9 a.m.), in the afternoon (1 p.m.) and in the evening (7 p.m.).

Within the trial plot, the effect of irrigation was also analysed, for which there was a perfect opportunity as one part of the plot was irrigated while another was not. In the Figure 2, points $a$; $b$; $c$; indicate the irrigated area while the points $d ; e ; f$ show the location of the non-irrigated plots. Points $a$; $d$ show the ploughed area, $b, e$ the strip tillage plots, while points $c, f$ the subsoiling plots.

Differences were analysed with the RStudio statistical system. Analytical values were measured in ppm, which was converted to $\mathrm{g} / \mathrm{m}^{2} / \mathrm{h}$ using the following formula (Zsembeli et al., 2009):

$$
\mathrm{F}=\mathrm{d} *(\mathrm{~V} / \mathrm{A}) *\left(\mathrm{C}_{2}-\mathrm{C}_{1}\right) / \mathrm{t} * 273 /(273+\mathrm{T})
$$

Figure 1: Measurement with the TESTO 535 gas analyser in the experimental plot (Látókép, 2018)

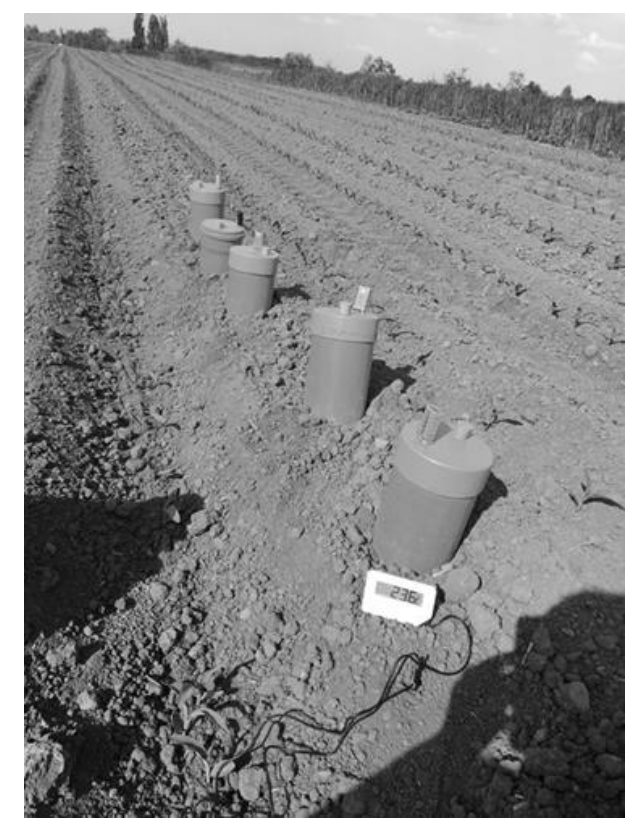

Source: own picture

Figure 2: Our experiment site (Látókép, 2018)

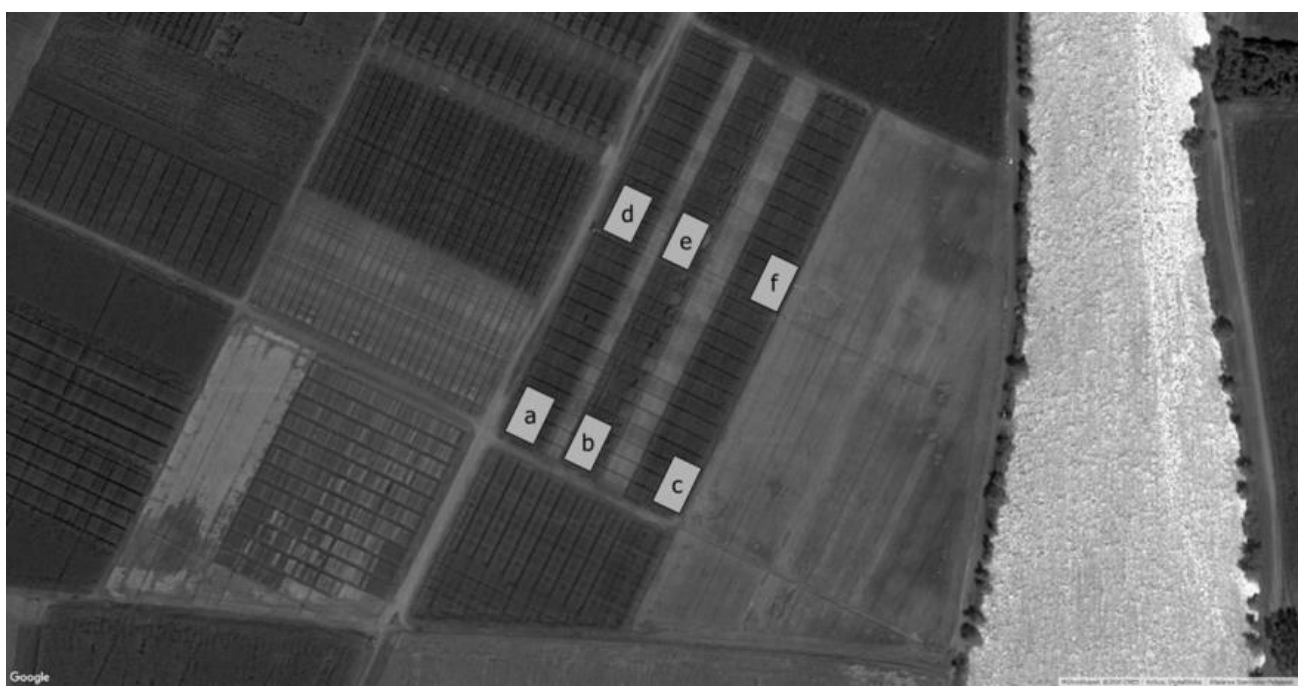

\section{RESULTS AND DISCUSSION}

In the course of the study the tillage - influencing role of carbon dioxide was analysed at different times of the day, as well as the common effects of irrigation. By means of a repeted measures anova statistical method (according to Huzsvai) the obtained values were examined and compared (Table 1). The post hoc test (Student Neuman Klaus) resulted in significant difference $(\mathrm{P}<0.05$ when different periods of the day and the cultivation methods were compared. Significant values were not obtained in ploughed and strip tillage cultivation. 
Common effects of the measurement time and tillage treatments

\begin{tabular}{lllll}
\hline & Df & Sum Sq & Mean Sq & F value \\
\hline measurement_time & 3 & 573.8 & 191.27 & 2.856 \\
tillage:measurement_time & 6 & 1028.8 & 170.46 & 2.560 \\
Residuals & 36 & 2410.8 & 66.97 & 0.0306 \\
\hline
\end{tabular}

Note: Signif. codes: $* * * 0,001 \%$; ns= non-significant

Examining the different periods of the day (Figure $3)$, the highest total emission values were measured during the morning hours at $6.45 \mathrm{~g} / \mathrm{m}^{2} /$ day, while the lowest value was measured in the early morning hours $\left(3.36 \mathrm{~g} / \mathrm{m}^{2} /\right.$ day). Difference between evening and early morning measurements was not significant, while morning and afternoon values were significantly different, especially the ones measured in the early morning. Our conclusion from this measurement was that the highest emission values were measured during the morning hours when the soil started to heat up (Figure 3).

Figure 3: Effect of daily flux on the $\mathrm{CO}_{2}$ emission of soil (Látókép, 2018)

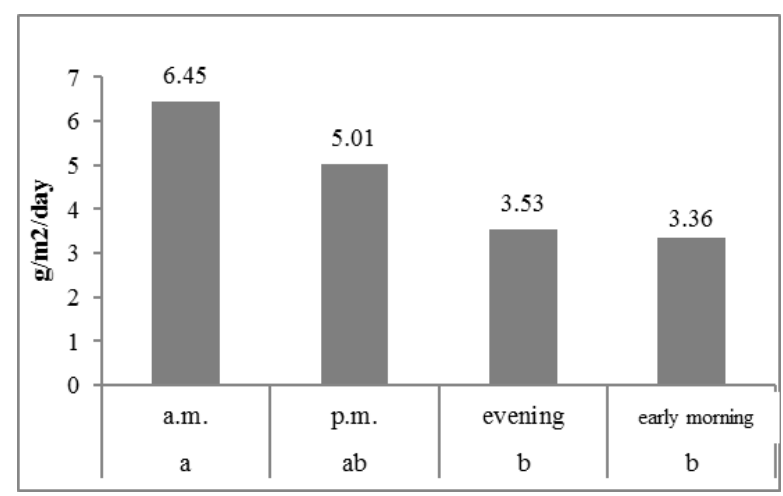

At the early morning hours the soil temperature was the same level, around $20{ }^{\circ} \mathrm{C}$ in al type of the treatments, but around 9 a.m. it started heat up, mainly in the winter ploughed part of our experimental plot. The results were $24{ }^{\circ} \mathrm{C}$ in the afternoon and evening hours (Figure 4).

As for irrigated and non-irrigated plots (Figure 5), emission values of the non-irrigated plots were higher $\left(5.46 \mathrm{~g} / \mathrm{m}^{2} /\right.$ day $)$, while the measured value of irrigated areas was $3.72 \mathrm{~g} / \mathrm{m} 2 /$ day. The reason behind the above might be related to the soil compaction of irrigated areas.
Figure 4: Soil temperature data under the daily flux examination (Látókép, 2018)

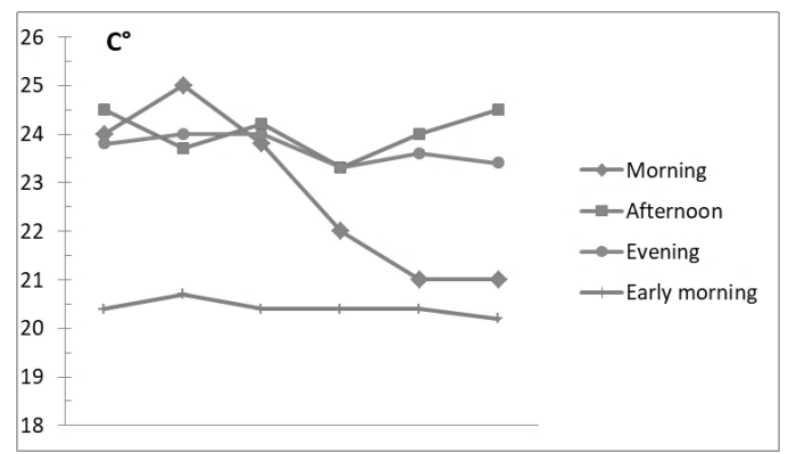

Figure 5: Effect of moisture on the $\mathrm{CO}_{2}$ emission of soil (Látókép, 2018)

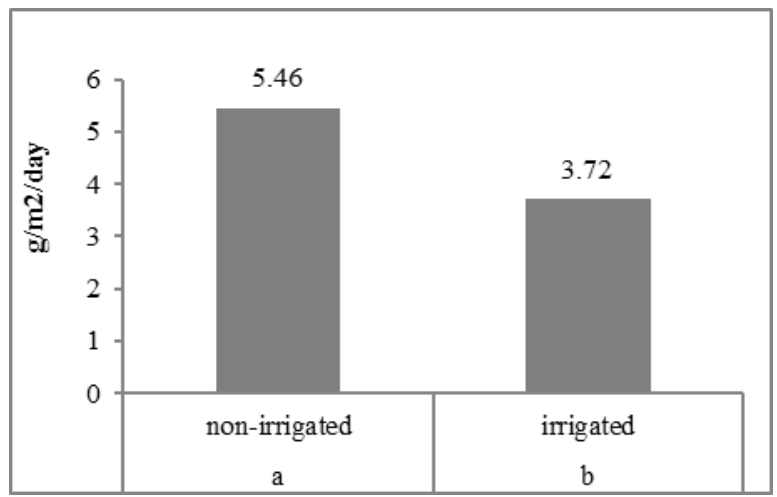

Summarizing the results, the analysis of tillage methods and different periods of the day (Figure 6) showed that the highest values were obtained in the case of winter ploughing $\left(20.21 \mathrm{~g} / \mathrm{m}^{2} /\right.$ day, 13.46 $\mathrm{g} / \mathrm{m}^{2} / \mathrm{h}, 12.24 \mathrm{~g} / \mathrm{m}^{2} /$ day). The lowest value was obtained at in the case of subsoiling during the evening hours $\left(2.30 \mathrm{~g} / \mathrm{m}^{2} /\right.$ day $)$. Due to the deficiency of the measurement device, afternoon values of winter ploughed plots showed negative values according to the statistical analysis, therefore this value could not be taken into account. 


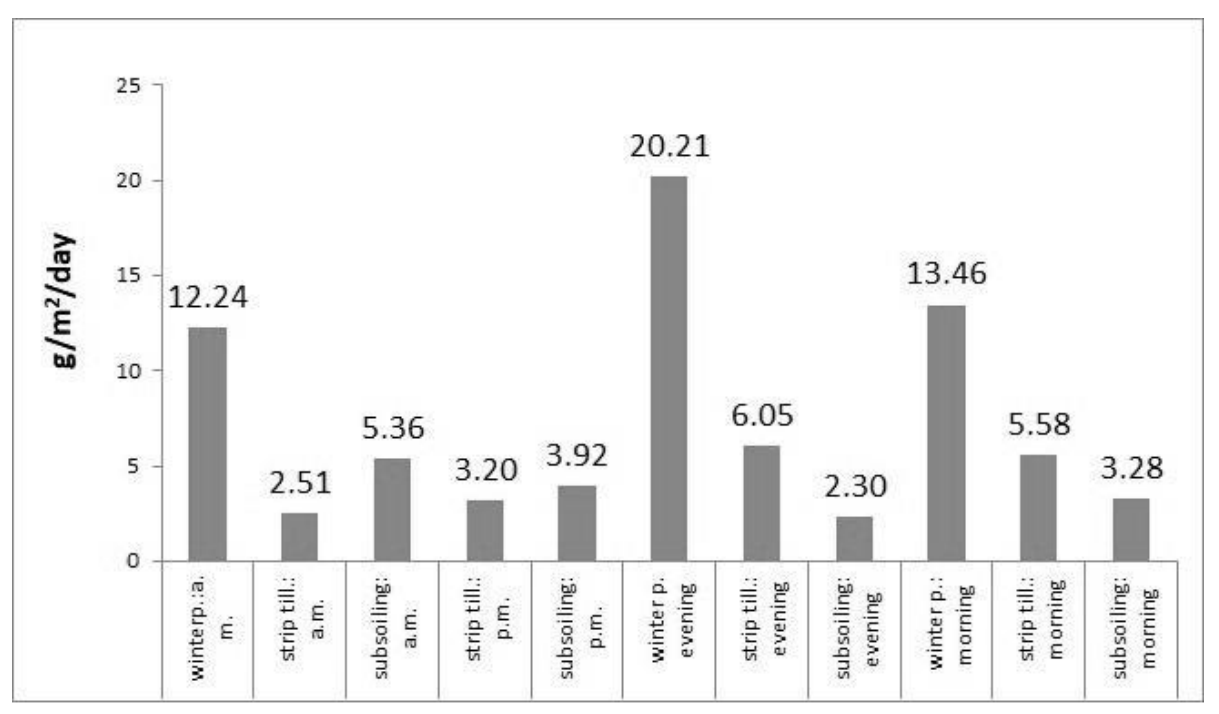

With regard to the temporal analysis (different periods of the day), emission of evening hours was low in the case of subsoiling, but as for winter ploughing, the highest value was obtained in that case. Overall, the winter ploughed emissions showed higher values during every period of the day, while the values of subsoiling were overall the lowest.

\section{CONCLUSION}

The results showed us that less carbon dioxide is emitted into the atmosphere from less disturbed soils, which contributes to the organic matter retaining ability of the soil. Our article points out which is that time of the day when the emission is higher in the different part of our experiment site. Regarding the highest value of the emission, the less disturbed soil showed less emission too. The conservation agriculture is not widespread yet, but more and more studies deal with it around the World.

The carbon-dioxide emission from the soil is just a slice of the whole global emission, but as the agriculture is very important factor regarding the GHG gasses, we have to care about it. The global climate change is a very crucial point for our Globe that is why we have to find a complex solution for this problem.

\section{ACKNOWLEDGEMENT}

The work/publication is supported by the EFOP3.6.3-VEKOP-16-2017-00008 project. The project is co-financed by the European Union and the European Social Fund.

\section{REFERENCES}

Bartholy, J.-Bozó, L.-Haszpra, L. (2011): KLÍMAVÁLTOZÁS 2011 Klímaszcenáriók a Kárpát-medence térségére. p.:31.

Birkás, M.-Gyuricza, Cs. (2004): A talajhasználat és a klimatikus hatások kapcsolata. [In: Birkás M.-Gyuricza Cs. (szerk.) Talajhasználat, müveléshatás, talajnedvesség] Quality-Press Nyomda \& Kiadó Kft. 10-47.

Borken, W.-Muhs, A.-Beese, F. (2002): Changes in microbial and soil properties following compost treatment of degraded temperate forest soils. Soil Biol. Biochem. 34: 403-412.

Dunn, S. (2001): Az energiatermelés széntelenítése. In: A világ helyzete 2001. Föld Napja Alapítvány, pp: 98-121.

Hanson, P. J.-Edwards, N.-Garten, C. T.-Andrews, J. A. (2000) Separating root and soil microbial contributions to soil respiration: A review of methods and observations. Biogeochemistry 48: 115-146.

Haszpra, L. (2004): Üvegházhatás, üvegházgázok. Természet Világa, II. különszám, 21-24.

Huzsvai, L. (2013): Variancia - analízisek az R-ben. Seneca Books. Debrecen.
Kaye, J. P.-Hart, S. C. (1998): Restoration and canopy-type effects soil respiration in a Ponderosa Pine Bunchgass ecosystem. Soil Science Economy. Am. J. 62: 1062-1072.

Kuzyakov, Y. (2006): Sources of CO2 efflux from soil and review of partitioning methods. Soil Biol. Biochem. 38: 425-448.

Lal, R.-Kimble, J.-Follett, R.-Steward, B. A. (eds.) (1998a): Soil processes and the $\mathrm{C}$ cycle. Boca Raton, FL. CRC Press.

Lal, R.-Kimble, J.-Follett, R.-Steward, B. A. (eds.) (1998b): Management of Carbon sequestration in soil. Boca Raton, FL. CRC Press.

Robock, A. (1998): Evaluation of the AMIP soil moisture simulations. Global Planet Change. 19: 181-208.

Schlesinger, W. H. (1977): Carbon balance in terrestrial detritus. Annual Review of Ecology and Systematics, 8: 51-81.

Szöllősi, N.-Kovács, Gy.-Zsembeli, J. (2009): A talaj szén-dioxid emissziója árpa tarlón. Agrártudományi Közlemények, 2009/35: 95-102.

Wang, G.-Elthair, L. A. B. (2000): Ecosystem dynamics and the Sahel drought. Geophys. Res. Lett. 27: 795-798. 